\title{
WOKÓŁ SPORU O KRYTERIA ODPOWIEDZIALNOŚCI UNIWERSYTETU
}

\section{WPROWADZENIE}

Toczący się w Polsce spór o autonomię instytucji publicznych przybiera na sile. Jego przyczyną w ostatnich miesiącach stały się zmiany legislacyjne dotyczące m.in. sposobu funkcjonowania wymiaru sprawiedliwości. Dochodza do tego liczne zapowiedzi rządu Prawa i Sprawiedliwości odnośnie do - szerzej zakrojonej - reformy państwa. Jedna z nich jest, przygotowywana od ponad roku, reforma szkolnictwa wyższego. W przeciwieństwie do innych grup zawodowych, środowiska akademickie (przynajmniej ich część) przyjęły zaproszenie min. Jarosława Gowina do wspólnej pracy nad projektem uwzględniającym ograniczenia, potrzeby oraz możliwości polskiego uniwersytetu ${ }^{1}$. Gwoli uczciwości wyjaśnić należy, że powściagliwy stosunek akademików do tego przedsięwzięcia tłumaczy nie tylko ich troska o powierzone im dobro. Oceniając rzecz z perspektywy antropologii kulturowej, po 1989 r. reformowanie uniwersytetu stało się rytuałem - by nie rzec powszednim obrzędem - władzy politycznej. Był więc czas, by się przyzwyczaić.

Poczyniona uwaga wiedzie do pytania o skutki dostosowania się polskich środowisk akademickich do politycznych realiów. Doprecyzowując myśl: jak w owych realiach - możliwe jest godzenie tego, co leży w interesie uniwersytetu, z oczekiwaniami elit politycznych oraz jego zobowiązaniami społecznymi? W artykule zatytułowanym Stowa i czyny. O Społecznej (nie-)odpowiedzialności uniwersytetu sformułowałem tezę zbieżna $\mathrm{z}$ jego tytułem². Zarzuciłem polskiemu uniwersytetowi ${ }^{3}$, że troszcząc się o dobro własne (w tym zabiegając o przychylność politycznej zwierzchności), zapomina o tych, którym ma służyć wiedza, radą i dobrym przykładem. Zarzuty tej treści nie mogły utrzymać się bez dowodu. Tymczasem trudność z jego przeprowadzeniem polegała na tym, że przedmiotem dowodzenia była okoliczność negatywna. Nieodpowiedzialność uniwersytetu nie tyle potwierdzać miały (określone) decyzje jego włodarzy, ile brak rozwiązań systemowych decydujących o możliwości sprawowania nad nim społecznej kontroli.

\footnotetext{
${ }^{1}$ Por. <http://www.nauka.gov.pl/ustawa20> [dostęp: 23.06.2017].

2 „Annales. Etyka w Życiu Gospodarczym” 20, 2017, nr 3, s. 37-48.

${ }^{3} \mathrm{~W}$ swoim artykule pojęciem uniwersytetu posługuję się szeroko - traktuję je jako synonim uczelni wyższej.
} 
Owszem, nie brakuje przykładów świadczących o niedostatecznym zaangażowaniu uniwersytetu w sprawy publiczne, względnie o jego podatności na sterowanie zewnętrzne. Dobrowolnie pozbawił się on prawa do własnej oceny kandydatów na studia (łącząc procedurę naboru z wynikami „nowej matury"), przyją system boloński (z zachowaniem stopnia doktora habilitowanego i tytułu profesora), zaakceptował stanowisko kolejnych rządów zabiegających o podniesienie współczynnika scholaryzacji (pomimo widocznych szkód, do jakich doprowadziła taka polityka) ${ }^{4}$. Decyzje te dają do myślenia. Nie maja jednak mocy rozstrzygajaccej. Nie przesądzają o winie uniwersytetu, gdyż w każdym z wymienionych przypadków wątpliwości budzi, 1) kto - finalnie - podjął owe decyzje; 2) jak szacować korzyści i straty będące ich następstwem oraz 3) czy poszczególne błędy zarządcze są wystarczająca podstawą do tego, by dokonać kompleksowej oceny uniwersytetu.

Mając na względzie powyższe, trzeba rozważyć, jak mierzyć społeczną odpowiedzialność wyższych uczelni. Skoro fakty nie tłumaczą się same, co decyduje o użyteczności przywołanej doktryny jako kryterium ewaluacyjnego? Ponad wszelką wątpliwość czynnikiem rozstrzygającym są jej walory rozjemcze i porządkujące. Przed jej zastosowaniem należy ustalić, co odróżnia społeczną odpowiedzialność jako obietnicę (bez pokrycia) od odpowiedzialności jako gwarancji podlegającej kontroli tych, którym została ona udzielona. Nie bez znaczenia w tym postępowaniu pozostaje wiedza o faktach przytoczonych w poprzednim akapicie. Ważniejsze od niej wydają się jednak przesłanki (negatywne) mówiące o tym, czego nie czyni oceniana instytucja. W przypadku polskiego uniwersytetu przesłanki te świadczą o istnieniu symbolicznych zatorów utrudniających (bądź uniemożliwiających) krytykę jego działań. Nawet jeśli pojawiają się jego adwersarze, ich społeczna słyszalność jest znikoma.

Za słusznością tego domniemania przemawiaja dwie kwestie. Z jednej strony, społeczne otoczenie uniwersytetu ma się o co upominać. Na czoło wybija się tu obniżająca się jakość kształcenia, zacieranie się dystynkcji odróżniającej (do niedawna) ludzi wykształconych od niewykształconych, zaniechania dotyczące społecznej mediacji czy nieobecność akademickiego przewodnika w sporach politycznych. Z drugiej strony ani członkowie tej instytucji, ani jej zewnętrzni interlokutorzy nie palą się do tego, by jej cokolwiek wytykać. Czy wynika z tego, że nie dostrzegają jej mankamentów albo że owe mankamenty im nie przeszkadzają? To bardzo wattpliwe. Dokonane ustalenia wiodą raczej do wniosku, że mamy do czynienia z wytwarzaniem przez uniwersytet pozorów społecznej odpowiedzialności, połączonym z tłumieniem głosu jego oponentów.

Rzeczoną hipotezę uzupełnia refleksja nad standardami etycznego zarządzania procesem kształcenia przyjętymi na szczycie UN Global Compact Leaders w 2007 r. w Genewie (Six Principles of PRME) ${ }^{5}$. Wobec rosnącego zainteresowania tą propozycją potraktować ją można jako brakujące ogni-

${ }^{4}$ Por. K. Leja, Zarzqdzanie uczelniq. Koncepcje $i$ wspótczesne wyzwania, Oficyna a Wolters Kluwer business, Warszawa 2013, s. 183-208.

${ }^{5}$ Foundation for the Global Compact <http://www.unprme.org/about-prme/index.php>. 
wo w badaniach nad społeczną odpowiedzialnością uniwersytetu w Polsce ${ }^{6}$. Wzmiankowany brak nie przesądza o słuszności wcześniej sformułowanych zarzutów. Ponieważ jednak wywołuja one liczne obiekcje - zwłaszcza tych, którzy bagatelizuja znaczenie komunikacyjnych uchybień uniwersytetu, względnie nie dostrzegają ich wcale - zasadne wydaje się ich uzupełnienie o wiedzę o przekonaniach międzynarodowego środowiska akademickiego na temat tego, jak być powinno. Zagadnienie to stanowi motyw przewodni niniejszego artykułu. Za pomoca zasad odpowiedzialnej edukacji menedżerskiej (PRME) zamierzam przypomnieć, którzy partnerzy uniwersytetu podlegaja jego (szczególnej) ochronie oraz na czym ona polega Argumenty przytoczone wcześniej posłużą natomiast, by wykazać, że - w polskich realiach - ochrona ta nie jest należycie sprawowana ${ }^{7}$.

\section{O TYM, JAK BYĆ POWINNO. ZASADY ODPOWIEDZIALNEJ EDUKACJI MENEDŻERSKIEJ UN GLOBAL COMPACT}

Rozważania dotyczące roli etyki w kształtowaniu standardów postępowania środowisk akademickich poprzedza następujące spostrzeżenie. Przynajmniej od czasów Davida Hume’a (1711-1776) etyka postrzegana jest jako nauka słaba ${ }^{8}$. Miara jej słabości, według szkockiego filozofa, jest jakościowe przemieszanie zasad, które podmiot moralny ma obowiązek uwzględniać w swoim działaniu. Hume skupia się na dwóch pryncypiach. Sa nimi troska o innych oraz odpowiedzialność za siebie. Nie sposób wybierać pomiędzy nimi. Równie trudno jednak dokonać ich zestawienia w ramach - konsekwentnie uprawianej - teorii powinności. Z tego powodu Hume przekazuje inicjatywę użytkownikowi owych zasad. Uwikłany w powszednie interakcje nie tylko dokonuje on wyborów moralnych, lecz także włącza się w debatę z innymi na temat (zadowalających możliwie wszystkich) standardów postępowania. Hume nazywa te standardy konwencjami, czyniąc z nich miarę moralnego i politycznego zdrowia wspólnoty państwowej ${ }^{9}$.

\footnotetext{
${ }^{6}$ Por. M. Roszkowska-Śliż, Odpowiedzialna edukacja na odpowiedzialnych uczelniach, Forum Odpowiedzialnego Biznesu <http://odpowiedzialnybiznes.pl/artykuly/odpowiedzialna-edukacja-na-odpowiedzialnych-uczelniach/> oraz: <http://ungc.org.pl/info/2017-global-forum-for-responsible-management-education-10-years-of-prme/>, a także: <http://ue.poznan.pl/pl/ uniwersytet,c13/wydzialy,c18/wydzial-ekonomii,c19/katedra-socjologii-i-filozofii,c2966/ aktualnosci,c2973/konferencja-3-4-04-2017-r,a57678.html>.

${ }^{7}$ Por. Zasady odpowiedzialnego kształcenia menedżerów (PRME); „Rzeczpospolita” z 4 lipca 2012 r. Etyka biznesu; <http://archiwum.rp.pl/artykul/1155582-Zasady-odpowiedzialnego-ksztalcenia-menedzerow-(PRME).html>.

${ }^{8}$ J. Hołówka, Relatywizm etyczny, PWN, Warszawa 1981, s. 135, 269-273.

${ }^{9}$ D. Hume, Traktat o naturze ludzkiej, tłum. C. Znamierowski, PWN, Warszawa 1963, s. 294-295; por. idem, Badania dotyczqce zasad moralności, tłum. M. Filipczuk, T. Tesznar, Zielona Sowa, Kraków 2005, s. 37-90.
} 
Zaproponowany przez Hume'a schemat postępowania badawczego nie aspiruje do miana nienaruszalnej podstawy nowoczesnej refleksji etycznej. Zyskuje natomiast na znaczeniu w odniesieniu do etyk stosowanych. W ich przypadku zróżnicowanie perspektyw aksjologicznych zapowiadane jest przecież w ich nazwie. Pytając o to, co słuszne, nie wolno lekceważyć norm sprawnościowych. Które z nich sa ważniejsze? Rozstrzyganie tego zagadnienia w niewielkim stopniu pomoże tym, których podzielił spór o wartości obowiązujące w przestrzeni działań kolektywnych. Uczestnicy sporu są bowiem wyrazicielami różnych przekonań normatywnych. Dzieli ich nie tylko różne pojmowanie tego, czym jest sprawiedliwość, lecz także jakie znaczenie nadają oni - nominalnie tym samym - regułom postępowania. Mając to na względzie, badania dotyczace relacji uniwersytetu z jego społecznym otoczeniem należy powiązać z pytaniem, o taką postać ładu spontanicznego, którego wyróżnikami są: 1) dynamiczna równowaga uprawnień interlokutorów; 2) ich kontrola wzajemna oraz 3) refleksyjność przejawiajacca się ich uczestnictwem w publicznej debacie na temat potrzeb i pragnień wspólnoty, do której przynależą ${ }^{10}$.

Jeżeli celem owych poszukiwań mają być standardy postępowania obowiązujące uczestników życia akademickiego, to trzeba przekazać inicjatywę samym zainteresowanym. Doprecyzowując myśl, akcent pada na dominujących aktorów tej sceny. To oni muszą ustalić, jak godzić (dobrze pojęty) interes własny ze zobowiązaniami wobec odbiorców finalnych produktu akademickiego. Odpowiedź tegoż otoczenia - na etyczne zagadnięcie akademików - zasadnie aspirować może do miana poszukiwanego kryterium społecznej odpowiedzialności uniwersytetu. W tym kontekście dziesięcioletnie starania środowisk akademickich skupionych wokół inicjatywy UN Global Compact o upowszechnienie standardów postępowania wolnych od zarzutu arbitralności uznane być mogą za cenną inspirację (punkt odniesienia) w badaniach nad kondycją moralną uczelni wyższych w Polsce. Tytułem dopowiedzenia, za teza o słuszności owych standardów - poza ich treścią - przemawia liczba (kilkuset) uczelni, które uznały za swój obowiązek:

„- rozwijanie zdolności studentów do generowania w przyszłości zrównoważonej wartości dla biznesu i całego społeczeństwa (zasada 1);

- wdrażanie do programu kształcenia i innych działań akademickich wartości społecznej odpowiedzialności (zasada 2);

- tworzenie ram edukacyjnych, materiałów i środowiska, które umożliwia efektywne nauczanie odpowiedzialnego przywództwa (zasada 3);

- angażowanie się w koncepcyjne i empiryczne badania dotyczące roli biznesu w procesie tworzenia zrównoważonych społecznie, środowiskowo i ekonomicznie wartości (zasada 4);

- współprace z przedstawicielami świata biznesu w celu zwiększania wiedzy na temat wyzwań, przed jakimi stoją przedsiębiorstwa (zasada 5);

${ }^{10}$ K. Mannheim, Ideologia i utopia, tłum. J. Miziński. Test, Lublin 1992; P. Rotengruber, Ideologia, anarchia, etyka. Dyskurs ponowoczesny a 'dialog', Humaniora, Poznań 2000; P. Bourdieu, L.D. Wacquant, Zaproszenie do socjologii refleksyjnej, tłum. A. Sawisz, Oficyna Wydawnicza, Warszawa 2001, s. 104-127; por. M. Ziółkowski, Przemiany interesów i wartości spoteczeństwa polskiego, Humaniora, Poznań 2000, s. 62. 
- pobudzanie i wspieranie dialogu pomiędzy akademikami, liderami biznesu, przedstawicielami rządów, konsumentów, mediów, organizacji pozarządowych i innych grup interesariuszy na temat kluczowych kwestii zwiazzanych z CSR i zrównoważonym rozwojem (zasada 6)"11.

Nie bez znaczenia pozostaje fakt, że program PRME nakłada na jego uczestników wymóg cyklicznego przestawiania raportów informujących o postępie w implementacji przytoczonych zasad. Celem nadrzędnym tego przedsięwzięcia jest ochrona zasobów integracyjnych i rozwojowych uniwersytetu. Odróżnienia wymagają w związku z tym jego zadania edukacyjne (zasady 1-5) od zobowiązań dialogowych (zasada 6). Czymś innym są przecież decyzje odnośnie do kierunków studiów czy programu nauczania, czymś innym zaś praktyka komunikacyjna organizacji, której parametrami sa jej transparentność oraz otwartość na innych. Uniwersytet odpowiedzialny uczestniczy w procesie budowania społeczeństwa obywatelskiego, poddając się zarazem jego kontroli. Gdyby ograniczył się do pierwszej dyrektywy, „budowałby” owo społeczeństwo z pominięciem jego potrzeb i uprawnień (m.in. do partycypacji). Stąd wniosek, że o społecznej odpowiedzialności uniwersytetu przesądza jego umiejętność łączenia obu dyrektyw. Marny ten nauczyciel, który nie słucha swoich uczniów.

Ostatnia uwaga odsłania istotę problemu. Uniwersytet akumuluje kapitał wiedzy i umiejętności niezbędnych dla właściwego funkcjonowania organizmu społecznego. Zgromadzone kapitały uzasadniają następnie jego roszczenie do (monopolizowania uprawnień do) certyfikacji. To dyplom uczelni wyższej decyduje o tym, kto może wykonywać najpotrzebniejsze społecznie zawody. Trudno się temu dziwić. Kontrola spraw wspólnych poprzedzona być musi weryfikacją tych, którzy będą ją sprawowali. W tym - z pozoru prostym wnioskowaniu ujawnia się tymczasem następująca dysfunkcja. Jest nią samokontrola uniwersytetu sprawowana z pominięciem informacji zwrotnej. Gwoli ścisłości, uchybienie to traciłoby na znaczeniu w układzie jednowektorowym. Gdyby przyjacc, że uniwersytet potrafi lepiej od jego społecznych partnerów opisywać to, czego doświadczają oni na co dzień, że uczy ich, unikając zarazem ich błędnych podpowiedzi, wówczas wszystko byłoby w porządku. Jego rola ograniczałby się wówczas od ochrony i roztropnej dystrybucji zasobów intelektualnych. Tak jednak nie jest.

Ustrój demokratyczny opiera się na zasadzie swobodnej partycypacji w sferze publicznej. W perspektywie poznawczej przyznaje każdemu obywatelowi prawo do własnej oceny spraw wspólnych. W ujęciu normatywnym nazywa „wolą powszechną" - utrzymującą się w czasie - zbieżność poglądów danej zbiorowości na temat owych spraw ${ }^{12}$. Politologiczne pryncypia współgraja z treścią programu PRME. Jego zasada 6 (wsparta obowiązkiem raportowa-

${ }^{11}$ M. Roszkowska-Śliż, Odpowiedzialna edukacja na odpowiedzialnych uczelniach, Forum Odpowiedzialnego Biznesu, <http://odpowiedzialnybiznes.pl/artykuly/odpowiedzialna-edukacja-na -odpowiedzialnych-uczelniach/>.

12 J.-J. Rousseau, Umowa społeczna, tłum. B. Strumiński, PWN, Warszawa 1965, rozdz. I, II; por: J. Habermas, Filozoficzny projekt nowoczesności, tłum. M. Łukasiewicz, Universitas, Kraków 2000, s. 28. 
nia) nie pozostawia złudzeń co do tego, że uniwersytet $\mathrm{w}$ trybie dialogowym powinien pozyskiwać wiedzę o kryteriach jakości życia społecznego i gospodarczego ${ }^{13}$. Czy zatem pozyskuje ją w taki sposób? Temu zagadnieniu zostanie poświęcony następny punkt rozważań.

\section{ZANIECHANIA KOMUNIKACYJNE POLSKIEGO UNIWERSYTETU: O TYM, JAK JEST ${ }^{14}$}

Ocena instytucji publicznych pod kątem ich społecznej poprawności nie jest łatwa. Pośród wielu przeszkód dwie zasługują na szczególne uwzględnienie. Po pierwsze, czynność tę utrudnia brak stabilnej podstawy ewaluacyjnej. Ujmując rzecz lapidarnie, każdy ma swój pogląd na temat tego, czym jest sprawiedliwość. Po drugie, instytucje publiczne tym różnią się od organizacji komercyjnych, że oprócz roli oferenta dóbr społecznie pożądanych pełnią one funkcję wykonawcy zadań spoczywających na organach władzy państwowej i samorządowej. Wykonując zadania publiczne, instytucje te lokuja się pomiędzy partnerem społecznym i politycznym. To sprawia, że muszą one godzić ich rozbieżne oczekiwania. Z jakim skutkiem? Trudno mieć pretensje do (dominującej) instytucji wiedzy albo o to, że realizuje zadania powierzone jej przez politycznego zleceniodawcę, albo że zwraca się przeciwko niemu w imię (autonomicznie szacowanego) dobra wspólnego. Oba obowiązki wynikają przecież z jej misji. Problemem jest coś innego. Dotyczy on trybu, w jakim środowiska akademickie dokonują wyboru pomiędzy jednym i drugim. Czy w szacowaniu ich - społecznych i politycznych - zobowiązań górę bierze cnota czy interes własny? Odpowiedź na to pytanie warto poprzedzić następującą refleksją. Nietrudno o przykłady potwierdzajace oba domniemania. Dlatego w sporze o kondycję moralną uniwersytetu nie można ufać studium przypadku. Z analizy poszczególnych zdarzeń niewiele wynika, ze zdarzeń świadczących przeciwko sobie - jeszcze mniej. Trzeba więc zmienić sposób postępowania.

Proponowane zmiany obejmuja kilka czynności badawczych. Najpierw selekcji wymagają kryteria społecznej odpowiedzialności uniwersytetu ${ }^{15}$. Następnie akcent pada na jego błędy i nadużycia - obiektywnie - kolidujące z interesem społecznym. Na koniec zapytać należy o praktykę świadczącą o tym, że - pomimo pokusy dezercji - poddał się on społecznej kontroli. Na znaczeniu zyskują takie kwestie, jak zdolność rozeznawania się przez oponentów uniwersytetu w ich położeniu, ich bezpieczeństwo, sprawność argumentacyjna,

${ }^{13}$ W oryginale zapis ów brzmi: „Principle 6 | Dialogue: We will facilitate and support dialog and debate among educators, students, business, government, consumers, media, civil society organisations and other interested groups and stakeholders on critical issues related to global social responsibility and sustainability". PRME Steering Committee, <http://www.unprme.org/ about-prme/the-six-principles.phphttp://www.unprme.org/about-prme/the-six-principles.php>.

14 Szerzej omawiam tę kwestię w innym miejscu: P. Rotengruber, Słowa..., s. 37-48.

15 Por. M. Geryk, Społeczna odpowiedzialność uczelni, Oficyna Wydawnicza SGH, Warszawa 2012. 
a wreszcie wpływ na sprawy krytykowanej instytucji. Tytułem dopowiedzenia, krytyka uniwersytetu tyleż może być prowadzona przez jego zewnętrznych partnerów, co przez jego członków. Tym ciekawsze wydają się ustalenia odnośnie do wyników interwencji podejmowanych przez druga grupę interlokutorów. W ich przypadku bowiem kary za „donosicielstwo” względnie za „nieznajomość własnego miejsca w szeregu”, są dużo dolegliwsze niż te wymierzane krytykom zewnętrznym ${ }^{16}$.

Podążając obranym tokiem postępowania, miarą użyteczności (wybranej) definicji społecznej odpowiedzialności uniwersytetu jest jej zgodność z poglądami na temat tego, jak być powinno, żywionymi przez społeczeństwo obywatelskie. Powiązanie jednego z drugim mogłoby budzić wątpliwości, gdyby nie wskazówka zawierająca się w programie PRME. Wobec - zamierzonego - powiąania tego programu z pryncypiami zachodnich demokracji jego treść traktować można jak wiążąca deklarację środowisk akademickich. Jak refren powraca szósta zasada PRME, mówiąca o obowiązku inicjowania (a przynajmniej uczestnictwa) przez owe środowiska w publicznej debacie. Istota tego przedsięwzięcia sprowadza się do rozwiązywania kwestii spornych w dialogu uniwersytetu z politykami, przedsiębiorcami, studentami, konsumentami, dziennikarzami, organizacjami społecznymi a wreszcie interesariuszami i demaskatorami (sygnalistami). Żadna z wymienionych grup nie może być pominięta, żadnej nie wolno odbierać prawa do przemawiania we własnym imieniu. Nie należy tego czynić, o ile wynik debaty dostarczać ma wiedzy o standardach postępowania wiążących jej uczestników. Instytucją powołana, by pozyskiwać tę wiedzę, dokonywać sprawdzenia jej autentyczności, posługiwać się nią w budowaniu społeczeństwa obywatelskiego, jest uniwersytet ${ }^{17}$. Czy zatem wywiązuje się on z tych obowiązów?

Polski uniwersytet realizuje zadania edukacyjne powierzone mu przez administrację publiczna. Stawia czoła politycznym wyzwaniom, włącza się w działania inicjowane przez świat biznesu. Niestety, na owych grupach kończy się lista dialogowych partnerów uniwersytetu. Doświadczenie powszednie nie potwierdza, by jego władze - w podobny sposób - podchodzić miały do sporów pracowniczych, skarg studenckich, doniesień medialnych bądź oczekiwań społecznych dotyczących jego funkcji edukacyjnych i integracyjnych. Doświadczenie tego nie potwierdza, lecz także temu nie zaprzecza. Nie oznacza to jednak, że jesteśmy zdani na jego werdykt. Nie mniej wymowne są okoliczności negatywne odnoszące się do (komunikacyjnych) zaniechań uniwersytetu. Na pierwszy plan wysuwają się interesariusze i demaskatorzy (sygnaliści). Aby wyjaśnić, dlaczego (właśnie) ich nieobecność zasadnie aspirować może do mia-

16 Por. J. Wieczorek, Mobbing akademickich demaskatorów, <https://nfamob.wordpress.com/ tag/demaskatorzy/> [dostęp: 12.08.2016]; W. Korczyński, Błędy demaskatorów <http://www.nfa. pl/print.php?what=article\&id=600> [dostęp: 12.08.2016]; M. Geryk, op. cit.

17 A. Piotrowska-Piątek, Relacje szkót wyższych z interesariuszami zewnętrznymi. Konwent jako organizacja pomostowa, „Zeszyty Naukowe Politechniki Śląskiej. Organizacja i Zarządzanie” 2014, z. 76, s. 167-178; por. A. Wojciechowska-Nowak, Jak zdemaskować szwindel? Czyli krótki przewodnik po whistle-blowingu, Fundacja im. S. Batorego, <http://www.batory.org.pl/doc/Poradnik_Jak_zdemaskowac_szwindel_grudzien_2008.pdf>, s. 51-62 [dostęp: 16.07.2016]. 
na argumentu rozstrzygającego w badaniach nad społeczną odpowiedzialnością uniwersytetu, przypomnienia wymaga, kim oni są.

Zdaniem R. Edwarda Freemana interesariuszem jest każdy, kto uważa, że poniósł szkodę z winy przedsiębiorstwa, szkoły czy urzędu ${ }^{18}$. Poza pracownikami, klientami bądź kooperantami do grupy tej należą aktorzy powiązani z ocenioną organizacją zależnościami pośrednimi, tacy jak społeczność lokalna czy jej konkurenci. Miarą zapobiegliwości menedżera jest znajomość interesariuszy połączona $\mathrm{z}$ umiejętnością prognozowania zagrożeń, których mogą oni być sprawcami. Niestety tak zdefiniowanym ryzykiem trudno zarządzać. Zagrożenie jest bowiem wszechobecne. Zapewne to skłoniło Freemana do zmiany poglądów na trwałość (i powszechność) uprawnień przysługujących interesariuszom ${ }^{19}$. Wspólnie z Williamem M. Evanem uprawnienia te skojarzyli z etyką kantowska, nakładająca na organizację (imperatywny) wymóg ochrony podmiotowości - każdego bez wyjątku - uczestnika życia publicznego ${ }^{20}$.

Tymczasem argumentacja transcendentalna okazała się zawodna. Interesariuszy, zgodnie z przestrogą Ronalda K. Mitchella, należy traktować poważnie nie tylko wtedy, gdy pozostaja pod ochroną imperatywu kategorycznego. Nie mniejsze znaczenie mają ich - różne z pochodzenia - przekonania moralne. Bywają oni przecież natarczywi i silni ${ }^{21}$. Przedmiotem kolejnej korekty Freemana stały się zatem różnice w pojmowaniu reguł sprawiedliwości dzielące skonfliktowanych interlokutorów ${ }^{22}$. Nawet wtedy, gdy postępują oni uczciwie, nie można mieć pewności, czy formułując roszczenia przeciwko sobie, posługują się tą samą miara. Konsekwencją tego stanu rzeczy jest obowiązek łączenia przez zarządcę odpowiedzialności wobec interesariuszy z troską o dobro organizacji, którą kieruje. Musi on rozumieć swoich społecznych partnerów, a zarazem wiedzieć, co jest przedmiotem jego (szczególnej) opieki.

Podobnie ma się sprawa z postulatem pozyskiwania zaufania za pomoca mechanizmu demaskacji. Potwierdzona stosownymi gwarancjami gotowość poddania się społecznej kontroli napotyka przeszkodę w postaci uznania

18 R.E. Freeman, Strategic Management: A Stakeholder Approach, Pitman Publishing, Boston 1984, <https://www.researchgate.net/publication/228320877_A_Stakeholder_Approach_to_ Strategic_Management> [dostęp: 27.11.2016], s. 48; S. Young, Etyczny kapitalizm. Jak na powrót połaczyć prywatny interes z dobrem publicznym, tłum. W. Kisiel, Metamorfoza, Wrocław 2005, s. VIII.

${ }^{19}$ C. Wicks, R.E. Freeman, Organization studies and the new pragmatism: positivism, antipositivism, and the search for ethics, „Organization Science” 9(2), $1998<$ https://www.researchgate.net/publication/247824169._Organization_Studies_and_the_New_Pragmatism_Positivism_ Anti-Positivism_and_the_Search_for_Ethics> [dostęp: 23.08.2016].

${ }_{20}$ W.M. Evan, R.E. Freeman, Spótka i osoby żywotnie zainteresowane. Kapitalizm kantowski, w: L. V. Ryan, J. Sójka (red.), Etyka biznesu, W drodze, Poznań 1997, s. 186-187.

${ }^{21}$ R.K. Mitchell, B.R. Agle, D.J. Wood, Toward a theory of stakeholder. Identification and salience: defining the principle of who and what really counts, <www.ronaldmitchel.org/publications/mitchel\%20agle\%20wood\%201997> [dostęp: 17.12.2014]; por. T. Mendel, Partycypacja w zarzadzaniu współczesnymi organizacjami, Wyd. AE w Poznaniu, Poznań 2001, s. 16-18.

${ }^{22}$ R. Phillips, R.E. Freeman, A.C. Wicks, What stakeholder theory is not, „Business Ethics Quarterly” 2005, February, <https://www.researchgate.net/profile/Robert_Phillips7/publication/228238062_What_Stakeholder_Theory_Is_Not/links/0c96051a3bbdad0c7c000000.pdf> [dostęp: 28.08.2016]. 
przez organizację nadrzędności interesu publicznego nad zasadą poufności (wiążąca jej pracowników, kooperantów, ekspertów itd.). Ujmując rzecz zwięźle, etycy gospodarczy i teoretycy zarządzania charakteryzuja demaskację jako akt nielojalności uzasadniony intencją obrony dobra wspólnego. Sa oni zgodni co do tego, że demaskator jest osoba, która ujawnia tajemnice organizacji z pobudek etycznych, narażając się przez to na karę za „wścibstwo” bądź „donosicielstwo”. Zarazem badaczy zajmujących się tym zagadnieniem dzieli to, czy na uwagę opinii publicznej w równym stopniu zasługują demaskatorzy będacy jej (obecnymi bądź dawnymi) członkami, co ci lokujący się poza nia, względnie sytuujący się na jej obrzeżach. Kością niezgody jest miarodajny dostęp demaskatorów pozaorganizacyjnych do informacji niejawnych, ich niejasne intencje oraz (rzekomo) niższe ryzyko odwetu będącego następstwem aktu demaskacji ${ }^{23}$.

Spór o definicję demaskatora ma znaczenie, gdyż jego następstwem jest dokonująca się w świadomości zbiorowej - selekcja wzorców postępowania stosowanych $\mathrm{w}$ walce $\mathrm{z}$ organizacjami zagrażajaccymi porządkowi publicznemu. Trudno odmówić racji tym, którzy nie chca stawiać znaku równości pomiędzy najrozmaitszymi przejawami pieniactwa, podrażnionej ambicji czy oportunizmu a działaniem podejmowanym $\mathrm{w}$ interesie społecznym ${ }^{24}$. Wraz z tym jednak nie wolno tracić z pola widzenia niebezpieczeństwa polegającego na dyskredytowaniu wszystkich - bez wyjątku - aktorów wcielających się w rolę demaskatora. Owszem, jest tu miejsce na wątpliwości. Rzecz w tym, by nie przesłaniały one etycznej strony przedsięwzięcia. Łatwą do przewidzenia reakcją organizacji, której ciemne sprawy ujrzały światło dzienne, jest kwestionowanie wiarygodności informatora. Nazbyt szybkie opowiadanie się przeciwko niemu czy choćby obojętność wobec niego, skutkują tym, że dziecko zostaje wylane z kapiela. Mając to na uwadze, należy stwierdzić, że miarą zdrowia uczestników życia publicznego jest sprawność mechanizmów chroniących demaskatora.

Z dokonanego przybliżenia wynika, że choć interesariusze i demaskatorzy nie zawsze formułują roszczenia zgodne $\mathrm{z}$ interesem społecznym, to zasługuja na to, by ich wysłuchać. Wobec tego bowiem, że werdykt wydaje opinia publiczna, błędem byłoby pomijanie przez nią czegokolwiek, co dotyczy jakości życia wspólnotowego. Tu zaś interesariusze i demaskatorzy mają najwięcej do powiedzenia. Zarówno to, o co się upominają (ze względu na interes własny), jak to, co wytykają organizacji (ze względu na interes ogółu), czyni ich oczami i uszami zbiorowości, do której przynależa. Cóż zatem dzieje się, gdy wymienione zmysły ulegaja przytępieniu? Wtedy zbiorowość pada ofiarą tych, których nie była w stanie kontrolować. W przypadku przedsiębiorstw i urzędów, rzec by można, iż jest winna sama sobie. Inaczej natomiast ma się sprawa $\mathrm{z}$ uniwersytetem.

${ }^{23}$ P. Rotengruber, Interesariusz, demaskator... i ten trzeci. O zamieszaniu wokót kluczowych pojęć etyki gospodarcze, Prakseologia 158, t. 1, Warszawa 2016, s. 65-86.

24 J. Habermas, Faktyczność i obowiazywanie, tłum. A. Romaniuk, R. Marszałek, PWN, Warszawa 2005, s. 50-51. 
Oceniający musi dysponować wiedzą o zasadach funkcjonowania organizacji poddanej (jego) ocenie. Ocenia i jest oceniany odnośnie do wiedzy zastosowanej przez niego jako kryterium słuszności wniosków, do których doszedł. Zabiega następnie o wsparcie społecznego otoczenia. Jego partnerem (głównym) staje się wówczas opinia publiczna, zgodnie z rozpoznaniem Maxa Webera, wcielająca się w rolę obrońcy reguł „materialnej sprawiedliwości” ${ }^{25}$. Zwykle to ona podejmuje decyzję o tym, czy uznać jego racje. Niestety decyzje opinii publicznej nie są wolne od nacisków zewnętrznych. Równie łatwo poddaje się ona wpływowi własnych emocji, co ekspertów (z powodów kompetencyjnych) zniechęcających ją do angażowania się w zagadnienia szczegóło$\mathrm{we}^{26}$. Tu dochodzimy do pytania o warunki społecznej kontroli uniwersytetu. To jego zadaniem, jako dominującej instytucji wiedzy, jest wytyczanie granicy pomiędzy tym, co decyduje o prawidłowym przebiegu życia społecznego, a tym, co uznać należy za jego zdeformowana postać. Ponieważ te ustalenia budzą zaufanie opinii publicznej, nie kolidują ponadto z jej przekonaniami o tym, co leży w jej interesie, uniwersytetowi niezwykle łatwo dyskredytować swoich oponentów. Staje on mianowicie pomiędzy nimi a siła, od której wsparcia zależy powodzenie ich zamiarów. Parafrazując Michela Foucaulta, kiedy uniwersytet przeobraża się w instytucję „wiedzy-władzy”, trzeba przed nim bronić społeczeństwo ${ }^{27}$.

Ostatnia myśl może wywoływać obiekcje. Historia życia akademickiego w Polsce dostarcza wielu przykładów odpowiedzialności, wytrwałości, a nawet heroizmu ludzi nauki. Dowiedli oni, że wiedza to oręż nader skuteczny w walce ze społeczna niesprawiedliwościa. Czy zatem ich dokonania nie przeczą obawom wyrażonym $\mathrm{w}$ poprzednim akapicie? W żadnym razie. Wiedza tyleż służyć może aranżowaniu, co dekomponowaniu przestrzeni wolności obywatelskich. Na korzyść tego domniemania przemawiają m.in. wysiłki światowej społeczności akademickiej zmierzające do upowszechnienia programu PRME. Celem tego przedsięwzięcia jest wykorzystanie zasobów uniwersytetu do celów edukacyjnych i integracyjnych ${ }^{28}$. Natomiast obowiązek raportowania nałożony na uczestników programu ma chronić ich przez dryfem polegającym na (mimowolnej) zamianie publicznej debaty w akademicki monolog. Miejsce rozstrzygnięć generalnych w badaniach dotyczących społecznych funkcji uniwersytetu zajmuje refleksja nad jego aktualną kondycję moralną. Dwie kwestie wybijają się na czoło. Z jednej strony uwzględnienia wymagają zjawiska świadczące o rozchodzeniu się interesów uniwersytetu i jego społecznego oto-

${ }^{25}$ M. Weber, Gospodarka i społeczeństwo, tłum. D. Lachowska, PWN, Warszawa 2002, s. $710-711$.

${ }^{26}$ R.K. Merton, Teoria socjologiczna $i$ struktura społeczna, tłum. E. Morawska, J. Wertenstein-Żuławski, PWN, Warszawa 1982, s. 256-257; por. J. Habermas, Teoria i praktyka, tłum. M. Łukasiewicz, Z. Krasnodębski, Warszawa 1983, s. 61-68.

${ }^{27}$ M. Foucault, Trzeba bronić społeczeństwa, tłum. M. Kowalska. Wyd. KR, Warszawa 1998, s. 47-48; por. M. Philp, Michel Foucault, w: Q. Skinner, Powrót wielkiej teorii w naukach społecznych, tłum. P. Łozowski, Wyd. UMCS, Lublin 1998, s. 79-99.

${ }^{28}$ K. Mannheim, Ideologia i utopia, tłum. J. Miziński, Test, Lublin, 1992, s. 206; por. M. Ziółkowski, op. cit., s. 62-68. 
czenia $^{29}$. Tytułem przypomnienia, społeczeństwo obywatelskie traci zarówno na zamianie edukacyjnej jakości w liczbę osób przyjmowanych na studia, jak i na procederze certyfikowania „wszystkich, jak leci”. Zamiast rzeszy absolwentów szkół wyższych potrzebuje ono garstki fachowców dysponujących dyplomem potwierdzającym ich (wysokie) kwalifikacje. Tymczasem jest, jak jest: „matura, to bzdura”, studiować „każdy może...”.

Z drugiej strony społeczne przekonania dotyczące mankamentów uniwersytetu - nawet jeśli przekonania krzywdzące tę instytucję - z zasady nie wybrzmiewają w (około)akademickiej debacie. Zresztą samo to sformułowanie budzi wątpliwości. Doprawdy nie wiadomo, gdzie w polskich realiach toczy się owa debata. Owszem, są miejsca wyróżnione, takie jak senat, rada jakości kształcenia czy - poza murami wyższej uczelni - studia telewizyjne i radiowe. Niewiele jednak z tego wynika. Tych, którzy głosza, że toczy się dialog środowisk akademickich z rzecznikami interesu społecznego, najpierw zapytać trzeba o przypadki świadczące o tym że, rzecznicy ci w ogóle dochodzą do głosu, później o długofalowe skutki ich wystapień. Z połaczenia obu przesłanek wyłania się obraz instytucji autopoietycznej, tyleż akumulującej wiedzę o zasadach społecznie odpowiedzialnego zarządzania, ile niestosującej się do niej $^{30}$. Pojęciowe nawiąania do Niklasa Luhmanna i Ralfa Dahrendorfa nie są tu przypadkowe. Uniwersytet nie musi obawiać się o swoją przyszłość. Bez względu na to, jak bardzo zdystansuje się od społecznych partnerów, wciąż będzie im potrzebny jako dystrybutor uprawnień. Czerpiąc zaś rację swego istnienia z uprawnień (i środków) przekazywanych mu przez administrację publiczna, stawał się będzie częścią autopoietycznego systemu, którego badaniem zajmowali się przywołani autorzy.

\section{ZAKOŃCZENIE}

Badaniom podjętym w niniejszym artykule przyświecały dwa cele. Celem pierwszym (ogólnym) było ustalenie, czym jest społeczna odpowiedzialność uniwersytetu. Wobec niejasności towarzyszących definicji społecznej odpowiedzialności biznesu (CSR) oraz wielości jej zastosowań w odniesieniu do instytucji publicznych akcent położony został na uzasadnienie roszczenia do ważności tej doktryny. Uzasadnienie to, z jednej strony, obejmuje powody, dla których podmiot życia zbiorowego powinien się jej podporządkować, z drugiej - kryteria, za pomocą których jego społeczni partnerzy mogliby rozeznawać się w jego rzeczywistych intencjach. Wymienione przesłanki dały podstawę do zawężenia poszukiwań badawczych do dwóch tropów. Najpierw,

29 Pikanterii sprawie dodaje fakt, że wzmiankowanemu rozchodzeniu się interesów rzadko, by nie rzec nigdy, nie towarzyszy konflikt dzielący uniwersytet oraz elity władzy politycznej.

${ }^{30}$ N. Luhmann, Teoria polityczna państwa bezpieczeństwa socjalnego, tłum. G. Skapska, PWN, Warszawa, 1994; R. Dahrendorf, Nowoczesny konflikt społeczny. Esej o polityce wolności, tłum. W. Niepokólczycki et al., Czytelnik, Warszawa 1993. 
posiłkując się definicją zaproponowaną w innym miejscu ${ }^{31}$, społeczną odpowiedzialność uniwersytetu skojarzyłem z jego stosunkiem do interesariuszy i demaskatorów. Szerokie spektrum spraw z udziałem interesariuszy oraz doniosłość zagrożeń, o których demaskatorzy informuja społeczne otoczenie krytykowanej organizacji, to przesłanki wystarczające do tego, by upominać się o sprawność mechanizmu umożliwiającego upublicznienie komunikatów wysyłanych przez obie grupy.

Dyrektywę etyczną w tej postaci skojarzyłem następnie z treścią programu PRME. Mając na względzie liczbę uczelni, które - w ostatniej dekadzie stały się jego uczestnikami, przyjąłem, że streszcza on przekonania środowisk akademickich odnośnie do ich społecznych zobowiązań. Decydująca w owych rozważaniach jest zgodność jednego z drugim. Zaproponowana definicja społecznej odpowiedzialności uniwersytetu współgra z zasadami postępowania (PRME) przyjętymi na szczycie UN Global Compact Leaders w 2007 r. Ich kwintesencją (zasada 6) jest obowiązek pobudzania i wspierania przez wyższe uczelnie dialogu pomiędzy uczestnikami życia społecznego i gospodarczego. Pośród jego uczestników program PRME wymienia także akademików. Dyrektywa ta ma kapitalne znaczenie. Wynika z niej bowiem, że w dialogu społeczno-gospodarczym występują oni w podwójnej roli. Nadzorują jego przebieg, a zarazem biorą w nim udział jako równorzędni partnerzy innych interlokutorów (w tym jako adresaci krytycznych uwag dotyczących sposobu wywiązywania się przez nich z zadań publicznych).

Ostatnie stwierdzenie odsyła do drugiego celu artykułu. Było nim znalezienie odpowiedzi na pytanie o społeczna odpowiedzialność polskich uczelni wyższych. Rozstrzygnięcie tej kwestii okazało się trudne (by nie rzec niemożliwe) za pomoca danych szczegółowych. Jak w przypadku łysiny - z paradoksu Eubulidesa - przykłady nieprzestrzegania przez uniwersytet dialogowego pryncypium nie mają mocy rozstrzygającej. Od oceniającego zależy, czy uzna je za wyjątek od reguły czy za prawidłowość stawiająca uniwersytet w (jednoznacznie) złym świetle. Dlatego potrzeba czegoś więcej, niż studium przypadku. Aby rozeznać się w dominujących wzorach kultury organizacyjnej tej instytucji, należy poddać badaniu mechanizm, za pomoca którego komunikuje się ona ze swoim otoczeniem. Zgodnie z wytycznymi PRME przedstawionymi $\mathrm{w}$ poprzednim akapicie przedmiotem rekonstrukcji uczyniłem dwie funkcje tegoż mechanizmu: edukacyjną oraz partycypacyjna.

Uniwersytet z cała pewnością uczy. Lepiej lub gorzej, ale uczy. Prowadzi działalność naukowo-badawcza, zabiera głos w sprawach publicznych. Sprawność uniwersyteckiego mechanizmu komunikacyjnego w odniesieniu do jego funkcji edukacyjnych potwierdza więc praktyka. Niestety nie można tego powiedzieć o partycypacyjnych zastosowaniach rzeczonego mechanizmu. Tu praktyka wystawia uniwersytetowi nader złe świadectwo. Doprawdy nie wiadomo, w jakim trybie rozczarowani studenci, skrzywdzeni pracownicy (niższego szczebla), działacze społeczni czy zwykli obywatele mieliby zgłaszać swoje zastrzeżenia tak, by mieć choć cień nadziei na to, że cokolwiek wskóraja. Nie

${ }^{31}$ P. Rotengruber, Stowa..., s. 37-48. 
wiadomo, gdyż polski uniwersytet nie opanował dotąd umiejętności komunikowania się z nimi. Aby to wykazać, wystarczy zapytać o procedury chroniące interesariuszy, demaskatorów i innych interlokutorów uniwersytetu. Regulacji użytecznych w działaniach na rzecz społeczno-akademickiego partnerstwa zwyczajnie nie ma. Nie ma, tak jak nie ma interesariuszy i demaskatorów w otoczeniu uniwersytetu.

Okoliczność negatywna w przedstawionym kształcie wymaga dopowiedzenia. Dotyczy ono stanu faktycznego, przesądzajacego o potrzebie interwencji podejmowanych przez społeczeństwo obywatelskie. Wyrażona wątpliwość zyskiwałaby na znaczeniu, gdyby przyjąć, że uniwersytet nie jest nikomu nic winien. Nieobecność roszczeniodawców wynikałaby wówczas z faktu, że strona społeczna nie ma zastrzeżeń do sposobu jego funkcjonowania. Tak jednak nie jest. Nie warto po raz kolejny wytykać uniwersytetowi jego błędy. Warto natomiast pokusić się o wyjaśnienie przyczyn jego dysfunkcji dialogowych. Ich trwałość i dolegliwość świadczą o tym, że obywatelskość Polaków napotyka kolejna granicę w postaci akademickiego autorytetu niepoddającego się ani zewnętrznej, ani wewnętrznej krytyce. Aby to zmienić, potrzebny jest rachunek sumienia przedstawicieli tej instytucji. Szlak został przetarty m.in. przez Pierre'a Bourdieu. Czas najwyższy, by - wspólnymi siłami - stworzyć polska wersję homo academicus ${ }^{32}$. Od tego bowiem zależy powodzenie przedsięwzięcia polegającego na implementacji w naszym kraju zasad PRME.

dr hab. Przemystaw Rotengruber

Uniwersytet im. Adama Mickiewicza w Poznaniu

proten@amu.edu.pl

\title{
ON THE CRITERIA OF A UNIVERSITY'S SOCIAL RESPONSIBILITY
}

\author{
Sum mary
}

The purpose of the essay is twofold. Firstly, to formulate a definition of a university's social responsibility (which takes into account social expectations of this institution and its internal determinants). The final result of this research is the definition built on two concepts. On the one hand, it is the stakeholder policy, on the other hand, the whistle-blower policy. These criteria make a university transparent and open to social criticism. Secondly, the essay tends to establish whether Polish universities - treated as dominant institutions of knowledge - can be seen as responsible partner(s) of civil society. From the perspective of the Principles for Responsible Management Education (PRME), the more responsible university, the better the dialogical relationships with its social environment. This leads to the question whether the relationships of Polish universities with stakeholders and whistle-blowers - taken as the eyes and ears of civil society - are intensive enough.

${ }^{32}$ P. Bourdieu, Homo Academicus, Polity Press, Cambridge 1988. 
